\title{
SISTEM INFORMASI MANAJEMEN ORGANISASI PERANNYA DALAM PENGAMBILAN KEPUTUSAN DAN PEMECAHAN MASALAH
}

\author{
Adisel $^{1}$, Robeet Thadi ${ }^{2}$ \\ Institut Agama Islam Negeri Bengkulu ${ }^{1,2}$ \\ adisel@iainbengkulu.ac.id
}

\begin{abstract}
ABSTRAK
Tujuan penelitian, sistem informasi manajemen memberikan informasi yang akurat dan tepat waktu yang diperlukan untuk memudahkan proses pengambilan keputusan dan pemecahan masalah yang memungkinkan penyelenggaraan fungsi perencanaan, pengendalian, dan operasional dapat berjalan secara efektif. Pendekatan dalam penulisan ilmiah ini menggunakan pendekatan kualitatif metode deskriptif. Hasil penelitian ini menunjukkan bahwa pengembangan dan pengelolaan SIM dalam organisasi mampu memicu keputusan yang tidak hanya cepat dan akurat tetapi juga akan sejalan dengan praktik terbaik dalam organisasi secara efektif dan efisien. Informasi telah menjadi sumber penting untuk mengelola organisasi modern.
\end{abstract}

Kata Kunci: Sistem Informasi Manajemen (SIM), Pengambilan Keputusan dan Pemecahan Masalah

\begin{abstract}
The purpose of this research is that management information systems provide accurate and timely information needed to facilitate the decision-making and problem-solving processes that enable the implementation of planning, control and operational functions to run effectively. The approach in scientific writing uses a qualitative descriptive method. The results of this study indicate that the development and management of MIS in an organization is able to trigger decisions that are not only fast and accurate but will also be in line with the best practices in the organization effectively and efficiently. Information has become an important source for managing modern organizations.
\end{abstract}

Keywords: Management Information Systems (MIS), Decision Making and Problem Solving

\section{PENDAHULUAN}

Sistem informasi manajemen telah berkembang dengan pesat menyebabkan terjadinya perubahan yang cukup signifikan dalam pola pengambilan keputusan yang dilakukan oleh manajemen baik pada tingkat operasional (pelaksana teknis) maupun pimpinan pada semua jenjang. Perkembangan juga telah menyebabkan perubahan-perubahan peran dari para manajer dalam pengambilan keputusan, 
mereka dituntut untuk selalu dapat memperoleh informasi yang paling akurat dan terkini yang dapat digunakannya dalam proses pengambilan keputusan.

Sistem informasi manajemen, Populer dengan nama MIS. MIS menyediakan manfaat yang berharga untuk waktu untuk tenaga kerja. Karyawan tidak harus mengumpulkan data manual untuk pengajuan dan analisis. Sebagai gantinya, informasi yang dapat dimasukkan dengan cepat dan mudah ke dalam program komputer. Karena jumlahnya dari data mentah tumbuh terlalu besar bagi karyawan untuk analisa, analis bisnis dapat membangun program untuk mengakses data dan informasi dalam pertanyaan oleh dari manajemen. Dengan akses cepat informasi yang dibutuhkan oleh pemimpin dapat membuat keputusan yang lebih baik tentang prosedur, arah masa depan, dan perkembangan pesaing, dan membuat akses lebih cepat.

Penelitian sebelumnya tentang sistem informasi manajemen kaitannya dalam pengambilan keputusan, sistem informasi mutlak diperlukan dalam pengambilan keputusan yang logis sehingga membutuhkan pemahaman tentang masalah dan pengetahuan mengenai alternatif pemecahannya. Unsur-unsur dalam pengambilan keputusan yang perlu dipertimbangkan adalah tujuan dari pengambilan keputusan, identifikasi alternatif-alternatif keputusan untuk pemecahan masalah, perhitungan mengenai factor-faktor yang tidak dapat diperhitungkan sebelumnya atau di luar jangkauan manusia (Lipursari, 2013). Kemudian Fibriany (2016) sistem informasi manajemen sangat penting untuk membantu pengambilan keputusan bagi manajemen lini.

Sementara penelitian yang dilakukan oleh Najamudin (2016) dalam upaya mempertahankan eksistensi lembaga dalam mengimbangi kemajuan sistem informasi manajemen, maka diperlukan SDM yang memahami perkembangan teknologi informasi tidak terkecuali lembaga pendidikan Islam. Penelitian lain tentang problem solving seperti yang dilakukan oleh Sulasmono (2012) pemecahan masalah merupakan bagian dari keterampilan atau kecakapan intelektual yang dininali sebagai hasil belajar yang penting dan signifikan.

Berdasarkan penelitian sebelumnya sama-sama menggunakan studi kepustakaan melihat bagaimana system informasi manajemen dalam pengambilan keputusan. Namun penelitian ini menekankan bagamimana manajemen sistem informasi (MIS) sebagai sebuah sistem dalam pengambilan keputusan dan pemecahan masalah. Kemudian melihat organisasi sebagai sebuah objeknya melalui pemanfaatan teknologi informasi berbasiskan internet dalam pengambilan keputusan dan pemecahan masalah organisasi.

Meningkatnya penggunaan teknologi informasi, khususnya internet, telah membawa setiap orang dapat melaksanakan berbagai aktivitas dengan lebih akurat, berkualitas, dan tepat waktu. Setiap organisasi dapat memanfaatkan internet dan jaringan teknologi informasi untuk menjalankan berbagai aktivitasnya secara elektronis. Para pemimpin di berbagai organisasi juga diharapkan dapat 
dengan lebih mudah untuk menganalisis kinerjanya secara konstan dan konsisten dengan pemanfaatan teknologi informasi yang tersedia.

Sistem informasi manajemen berbasis komputer dalam kenyataannya banyak membantu pekerjaan manusia, jika dibandingkan dengan system informasi yang masih menggunakan cara-cara manual. Sebagai contoh adalah penyediaan informasi akademik yang berkaitan dengan data mahasiswa dapat dilakukan dengan cepat sehingga mutu layanan kepada mahasiswa dapat ditingkatkan (Adisel, 2020).

Manajemen membutuhkan banyak informasi agar dapat bekerja secara efisien dan efektif. Informasi yang banyak tersebut tidak mungkin seluruhnya dapat ditampung oleh manajemen. Untuk itu dibutuhkan suatu sistem yang dapat mendukung kebutuhan manajemen dalam mengelola suatu perusahaan/organisasi. Dengan adanya sistem informasi yang baik diharapkan tidak adanya penyimpangan-penyimpangan yang terjadi dalam perusahaan/organisasi. Selain itu suatu sistem yang baik juga akan mendorong produktivitas yang tinggi dan memberikan kontribusi atas tercapainya tujuan organisasi.

Pemanfaatan teknologi informasi ini dikaitkan dengan pentingnya atau bantuannya dalam proses pengambilan keputusan manajemen. Dapat kita ketahui bahwa masih kurangnya organisasi baik pada sektor publik maupun organisasi pada sektor swasta yang menerapkan sistem informasi manajemen dalam pengambilan keputusan dan pemecahan masalah. Tulisan ini mengulas tentang peran sistem informasi manajemen organisasi dalam pengambilan keputusan dan pemecahan masalah melalui analisis sistem informasi tentang decision-making, problem solving, dan mis and becision making, and problem solving.

\section{METODE PENELITIAN}

Pendekatan dalam penulisan ilmiah ini menggunakan pendekatan kualitatif metode deskriptif. Studi pustaka dipilih sebagai metode pengumpulan data. Menggunakan cara tersebut peneliti ingin menggambarkan bagaimana peran sistem informasi manajemen organisasi dalam pengambilan keputusan dan pemecahan masalah. Peneliti menggunakan buku, catatan, laporan, koran, majalah, jurnal dan internet yang sesuai dengan tema riset ini sebagai rujukan. Setelah data yang diperoleh dianggap memadai, selanjutnya data diolah untuk kemudian disimpulkan.

\section{HASIL PENELITIAN}

\section{Teknologi Informasi}

Sistem Informasi manajemen menurut Lucey has become synonymous with computer; yet, both concepts are not exactly the same because management information systems existed in the life of pre-modern organizations long before the advent of the computer technology. This argument is substantiated by the fact 
that computer was not in use when organizations kept records using traditional and manual mechanisms to manage information (Lucy, 2005).

Menurut Ottih bahwa It is important though to pinpoint that the computer takes credit for increased interest in management information systems because it eases and facilitates data processing as well as adds new vistas of interesting career options in MIS (Ottih, 1995). Bee \& Bee (1999) menjelaskan bahwa $a$ system to convert data from internal and external sources into information andcommunicate that information in an appropriate form, to managers at all levels in all functions toenable them to make timely and effective decisions for planning, directing and controlling the activities for which they are responsible.

Sistem Informasi Manajemen (M.I.S.) adalah pada dasarnya berkaitan dengan pengolahan data menjadi informasi. Pengumpulan data melibatkan penggunaan Teknologi informasi (TI) yang terdiri dari: komputer dan jaringan telekomunikasi (EMail, Voice Mail, Internet, telepon, dll). Komputer yang penting untuk lebih kuantitatif, dari kualitatif, pengumpulan data, penyimpanan dan pengambilan; Fitur khusus adalah kecepatan dan akurasi, dan penyimpanan sejumlah besar data. Telekomunikasi menyediakan sarana untuk satu arah atau komunikasi dua arah dan untuk transmisi pesan.

Proses aliran informasi dalam organisasi berjalanan secara dinamik, bagaimana pesan diciptakan, diseberkan dan diinterpretasikan. Ada tiga cara informasi mengalir atau menyebar pada organisasi, yakni: penyebaran pesan secara serentak, penyebaran pesan secara berurutan dan penyebaran pesan secara serentak-berutan (Thadi, 2020).

Kombinasi IT yang digunakan: telepon, komputer, prosesor, printer, dll. Banyak waktu dan uang yang disimpan dan keamanan data dan pesan dipastikan. Sebuah sistem informasi manajemen (MIS) memungkinkan perusahaan untuk memberikan jawaban pemimpin dalam mencari ilmu. MIS ini dilakukan dengan menggabungkan data mentah tentang operasi organisasi (yang terkandung dalam sistem information technology dasar) dengan informasi yang dikumpulkan dari karyawan dalam sistem pakar yang mencerminkan prosedur organisasi.

Namun, keberhasilan MIS dalam setiap organisasi memiliki banyak hubungannya dengan desain. Mengembangkan MIS efektif melibatkan upaya manajer serta orang-orang spesialis. Spesialis dibebani dengan penyediaan keahlian teknis. Lebih dari itu, spesialis fungsional harus terlibat untuk menawarkan ide-ide yang relevan mengenai spesialisasi mereka. Sebagai contoh, seorang akuntan harus menjadi bagian dari sistem informasi akuntansi, juga pemasaran, dan ahli sumber daya manusia dan sebagainya. Pembangunan MIS juga membutuhkan pengetahuan dari beberapa disiplin ilmu. Hal menarik dari berbagai dan berkembang seperti konsep dan teknik untuk berfungsi dengan baik. Untuk memiliki baik dan berguna MIS, pengetahuan yang memadai tentang interaksi dan hubungan di antara bidang-bidang ini adalah sine qua non. Penting 
untuk dicatat bahwa MIS setiap organisasi dapat dibagi lagi dalam sub sistem yang merupakan bagian fungsional dari organisasi.

\section{Decision - Making}

George and Jones menjelaskan bahwa Decision - making is the process by which organizational members choose specific course of action in response to threats and opportunities (George \& Jones, 1996). Menurut Daft (2001) bahwa Good decision result in courses of actions that help an individual, group or organization to be effective, the opposite is its reverse. Every organization grows, prospers or fails as a result of decisions made by its members; and decision according. Menurut Simon (1984) otoritas terkemuka dalam pengambilan manajemen keputusan menganggap bahwa pengambilan keputusan terdiri dari empat fase utama:

1. Intelligence searching the environment for conditions calling for decision making.

2. Design inventing, developing and analyzing possible courses of actions. This involves processes to understand the problem, to generate solutions and testing of solutions for feasibility.

3. Choice-selecting an alternative or course of action from those variables.

4. Review-assessing past choices. This model was later incorporated by George Huber into an expanded model of the entire problem-solving process

\section{Problem Solving}

Menurut Marzano et all (1988), problem solving adalah salah satu bagian dari proses berpikir yang berupa kemampuan untuk memecahkan persoalan. Jika Wickelgren mendefinisikan problem solving sebagai upaya untuk mencapai tujuan khusus, maka Van Dijk dan Kintsch dikutip Marzano sebagai menyatakan bahwa problem solving terjadi bila pencapaian tujuan tertentu mensyaratkan kinerja dan langkah langkah mental tertentu (Marzano, 1988).

Bagi Palumbo problem solving adalah fungsi dari cara bagaimana stimulus tertentu menjadi in-put melalui sistem sensori ingatan, diproses dan dikoding melalui memori kerja (working memory/short term memory) dan disimpan bersama asosiasi-asosiasi dan peristiwa-peristiwa (histories) yang sekeluarga dalam memori jangka panjang (Long Term Memory) (Palumbo, 1990).

Girl et.al (2002) menyatakan bahwa pemecahan masalah adalah proses yang melibatkan penerapan pengetahuan dan ketrampilan-ketrampilan untuk mencapai tujuan. Sedang menurut Gagne \& Briggs (1979), unjuk kerja pemecahan masalah itu berupa penciptaan dan penggunaan aturan yang kompleks dan lebih tinggi tingkatannya, untuk mencapai solusi masalah. 


\section{MIS And Decision Making, and Problem Solving}

Sistem Informasi Manajemen (MIS) pada dasarnya berkaitan dengan proses pengumpulan, pengolahan, penyimpanan dan transmisi informasi yang relevan untuk mendukung manajemen operasi dalam organisasi apapun. Dengan demikian, keberhasilan pengambilan keputusan, yang merupakan jantung dari proses administrasi, sangat tergantung sebagian pada informasi yang tersedia, dan sebagian di fungsi yang merupakan komponen dari proses. Misalnya, jika tujuan manajerial tidak ada atau tidak jelas, mungkin karena informasi yang tidak memadai, tidak ada dasar untuk pencarian. Tanpa informasi yang diperoleh melalui pencarian, tidak ada alternatif untuk membandingkan, dan tanpa perbandingan alternatif pilihan dari tindakan tertentu tidak mungkin untuk menghasilkan hasil yang diinginkan.

Menurut Lucey MIS may be viewed as a mean for transformation of data, which are used as information in decision-making processes. Figure 1 shows this understanding about information as data processed for a definite purpose (Lucey, 2005).

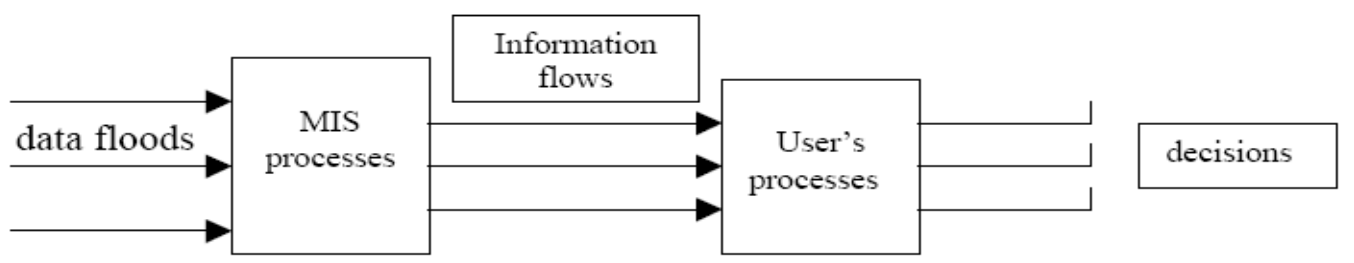

Gambar 1. MIS And Decision-Making Process

Ada begitu banyak definisi dari MIS. Untuk tujuan penelitian ini, MIS dapat didefinisikan sebagai sistem yang menyediakan manajemen dengan informasi yang akurat dan tepat waktu yang diperlukan untuk memfasilitasi proses pengambilan keputusan dan memungkinkan organisasi perencanaan, pengendalian, dan fungsi operasional harus dilaksanakan secara efektif. Jadi dengan cara ini MIS meningkatkan daya saing perusahaan dengan mengurangi biaya dan meningkatkan kecepatan pemrosesan.

\section{PEMBAHASAN}

Hampir semua organisasi bisnis biasanya memiliki beberapa jenis sistem informasi untuk manajemen, aturan akuntansi, kontrol stok dan monitoring sistem pasar adalah contoh yang paling tradisional dan umum. Kekuatan teknologi telah mengubah peran informasi dalam perusahaan bisnis. Sekarang informasi telah menjadi diakui sebagai sumber kehidupan suatu organisasi, dapat dilihat pada gambar 2. Tanpa informasi organisasi modern akan mati. Meskipun investasi besar dalam IT selama tahun terakhir, menunjukkan efek seperti investasi pada kinerja organisasi memilikiterbukti sangat sulit. MIS berbeda dari sistem informasi biasa karena tujuan utama dari sistem ini adalah untuk menganalisis 
sistem lain yang berhubungan dengan kegiatan operasional dalam organisasi. Dengan cara ini, MIS adalah bagian dari keseluruhan kegiatan perencanaan dan pengendalian yang mencakup penerapan manusia, teknologi, dan prosedur organisasi.

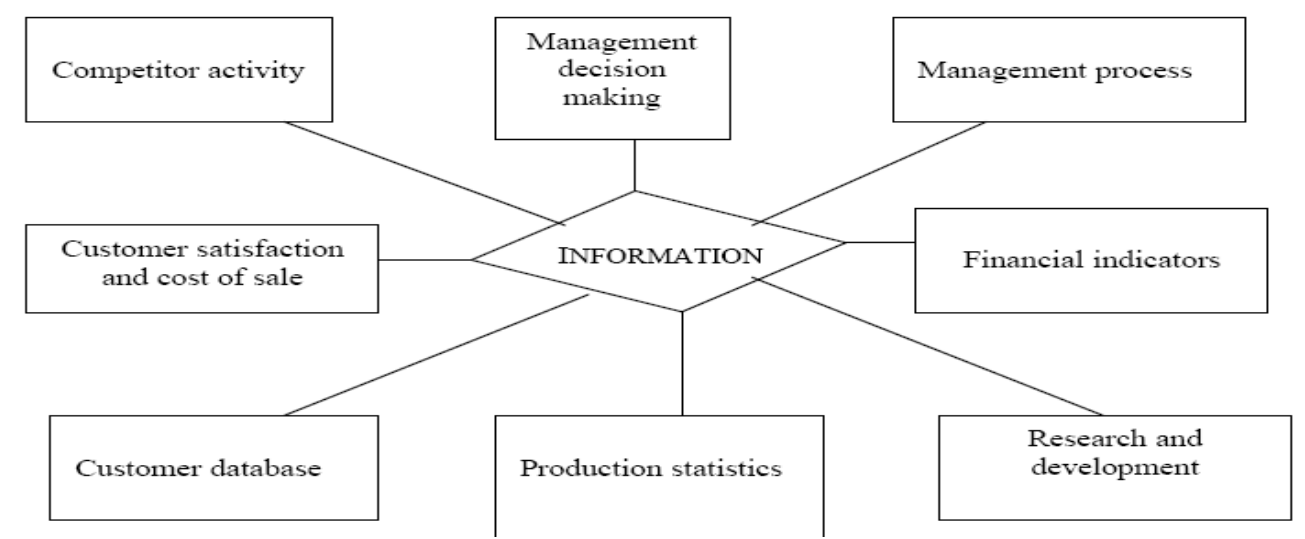

Gambar 2.Information the life-blood of the organization

Gambar berikut ini menunjukkan konseptual diskomposisi dari yang berbeda sistem manajemen dalam suatu organisasi. sistem informasi manajemen juga terkenal untuk vesting operasinya pada metode yang sistematis, yang menjamin bahwa keputusan dibuat dalam bisnis yang tertib dan terencana berlaku, mendorong objektivitas selama pengambilan keputusan dalam pemecahan masalah yang terjadi di organisasi. Dengan demikian, setelah penyaringan tersebut dilakukan, keputusan yang baik didorong, sementara yang buruk yang dibuang akhirnya, tindakan tersebut memastikan positif, dalam hal keputusan yang dibuat oleh organisasi, yang pada dasarnya menghubungkan langsung untuk memperbaiki proses pengambilan keputusan dari pemecahan masalah secara menyeluruh.

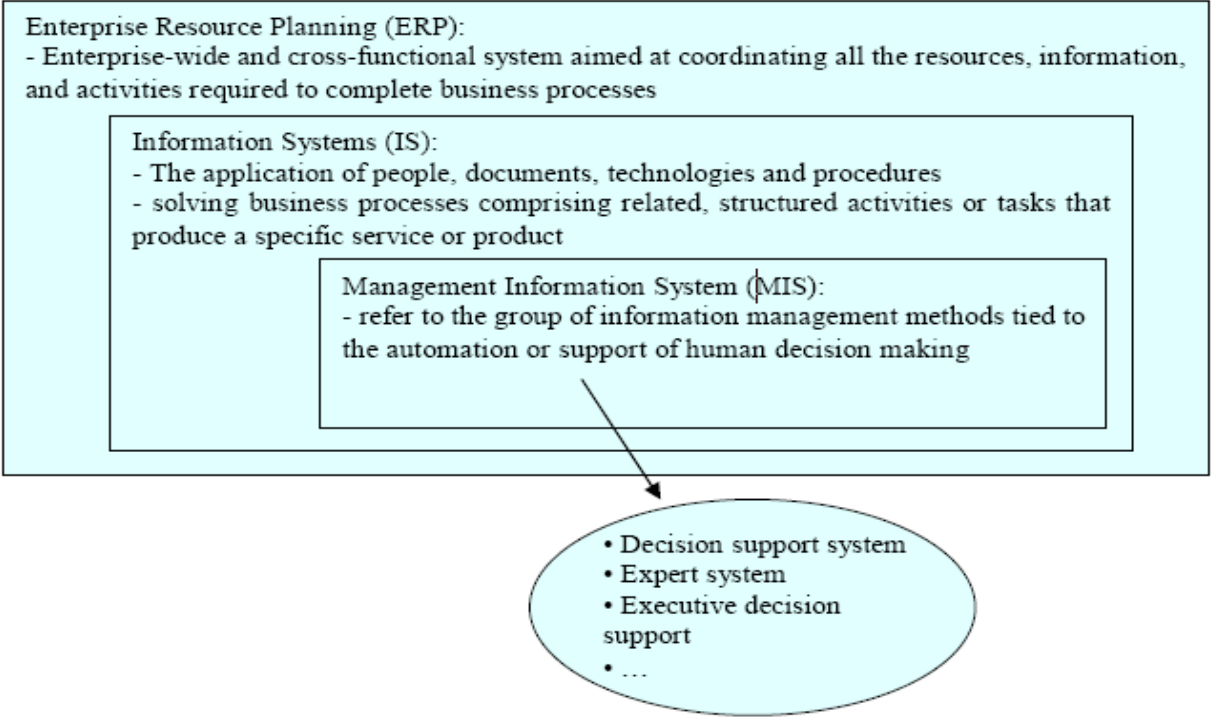

Gambar 3. Concept of management information systems 
Jika sistem informasi manajemen dibangun dengan baik dan terorganisir dengan baik MIS dapat menyediakan manajemen dengan pengetahuan itu perlu untuk mengurangi biaya operasi dan meningkatkan keuntungan. Sistem Informasi Manajemen dapat membantu meningkatkan manajemen efisiensi dengan cepat menyediakan kritis informasi tentang prosedur dan operasi.

\section{SIMPULAN}

Sistem informasi manajemen tidak diragukan untuk praktisi bisnis modern dan dunia pendidikan; sistem informasi manajemen organisasi perannya dalam pengambilan keputusan dan pemecahan masalah sangat penting guna memperoleh informasi yang akurat, tepat waktu, relevan, lengkap dan ekonomis. Sistem Informasi Manajemen menghasilkan. sumber informasi telah menjadi permintaan yang tinggi oleh organisasi dan MIS adalah satu-satunya pilihan untuk kepuasan tuntutan tersebut. MIS, pelaku usaha, sebagai suatu keharusan harus merangkul dan menekankan praktek dalam organisasi. Hal ini dapat dicapai melalui keterlibatan manajemen puncak dan sensitisasi keseluruhan setiap anggota organisasi fakta bahwa MIS telah menjadi alat penting dalam praktik bisnis yang efisien dan efetif untuk organisasi. Setiap bagian fungsional dari pondasi organisasi keharusan dari jumlah MIS organisasi dan mengembangkan sistem informasi manajemen fungsional mereka. Bila ini susah payah dikembangkan dan dikelola, pengambilan keputusan dalam organisasi tersebut tidak hanya akan lebih cepat atau lebih akurat tetapi akan sejalan dengan praktik terbaik industri dan pada akhirnya akan menghasilkan efisiensi dan efektivitas organisasi.

\section{DAFTAR PUSTAKA}

Adisel, A. (2020). Manajemen Sistem Informasi Pembelajaran. Alignment:Journal of Administration and Educational Management, 2(2), 105-112. https://doi.org/https://doi.org/10.31539/alignment.v2i2.900

Bee, R. \& Bee, F, (1999): Managing Information and Statistic. Trowbridge: Cromwell Press.

Daft, R. L. (2001): Organization Theory and Design, 7th ed. South Western Publishing, USA

Fibriany, F. W. (2016). Penerapan Sistem Informasi Manajemen Pada Pengambilan Keputusan di Departemen SDM. Cakrawala-Jurnal Humaniora, 16(2).

Gagne, R.M. \& Briggs, L.J. (1979). Principles of Instructinal Design. Second Edition; New York: Holt, Rinehart and Winston.

George, J. M. and Jones G. R. (1996): Understanding and managing Organizational behavior. 1st ed., Addison- Wesley Publishing Company Inc. USA. 
Girl, T.A., Wah, L.K.M., Kang, G.Ng., \& Sai, C.L. 2002. New Paradigm for Science Education. A Perspective of Teaching Problem-Solving, Creative Teaching and Primary Science Education; Singapore: Prentice Hall.

Lipursari, Anastasia. (2013). 'Peran Sistem Informasi Manajemen (SIM) dalam Pengambilan Keputusan,' Jurnal STIE Semarang, 5 (1). 26-37

Lucey, T. (2005): Management Information Systems. London: Book Power.

Marzano, R.J. et all, (1988). Dimension of Thinking: A Framework for Curriculum and Instruction. Viginia: Association for Supervision and Curriculum Development.

Najamudin, M. (2016). Sistem Informasi Manajemen terhadap Pengambilan Keputusan di Lembaga Pendidikan Islam. TADARUS, 5(1), 104-122.

Ottih, L. O. (1995): Management Information Systems: An integrated Approach New African publishing Co. Ltd Owerri.

Palumbo. D. B. (1990). Programming Language/Problem-Solving Research: AReview of Relevant Issue. Review of Educational Research; Spring. Vol. 60 (1), pp $65-89$.

Simon, H. A. (1984): Making Management Decisions: The role of intuition and emotion, Academy of management executive, 1(1). 57-64

Sulasmono, B. S. (2012). Problem Solving: Signifikansi, Pengertian, dan Ragamnya. Satya Widya, 28(2), 155-166.

Thadi, R. (2020). Audit Komunikasi Organisasi Layanan Akademik di IAIN Bengkulu. Jurnal Penelitian Komunikasi, 23(1). 